\title{
Relationship between organizational culture and commitment of employees in health care centers in west of Iran
}

\author{
Yadollah Hamidi ${ }^{1}$, Roghayeh Mohammadibakhsh ${ }^{2,3}$, Alireza Soltanian ${ }^{4}$, Masoud Behzadifar ${ }^{5}$
}

${ }^{1}$ Ph.D. of Health Management, Associate Professor, Social Determinants of Health Research Center, Department of Health Management, School of Public Health, Hamadan University of Medical Sciences, Hamadan, Iran

${ }^{2} \mathrm{Ph}$.D. Student of Health Policy, Deputy of Health, Hamadan University of Medical Sciences, Hamadan, Iran

${ }^{3}$ Ph.D. Student of Health Policy, School of Health Management and Information Sciences, Iran University of Medical Sciences, Tehran, Iran

${ }^{4} \mathrm{Ph} . \mathrm{D}$. of Biostatistics, Associate Professor, Modeling of Non-Communicable Diseases Research Center, Department of Biostatistics, School of Public Health, Hamadan University of Medical Sciences, Hamadan, Iran

${ }^{5} \mathrm{Ph} . \mathrm{D}$. Student of Health Policy, Health Management and Economics Research Center, Iran University of Medical Sciences, Tehran, Iran

Type of article: Original

\begin{abstract}
Introduction: Presence of committed personnel in each organization not only reduces their absenteeism, delays, and displacements but also leads to a dramatic increase in performance and efficiency of an organization, mental freshness of employees, better manifestation of noble objectives, and organizational mission as well as fulfillment of personal goals. Therefore, the purpose of this study was to determine the relationship between organizational culture and organizational commitment of employees in administrative units of health care centers in the cities of Hamedan Province based on the Denison model in 2015.

Methods: In this cross-sectional study, 177 employees in administrative units of health care centers in the cities of Hamedan Province were selected by a multistage stratified sampling method. The data collection instruments included the standardized Denison organizational culture survey and organizational commitment questionnaire by Meyer and Allen. Data were analyzed by IBM-SPSS version 21 using descriptive statistics and Pearson productmoment coefficient.

Results: Among the 12 indicators of organizational culture, the highest mean scores were assigned to empowerment (16.74), organizational learning (16.41), vision (16.4), and strategic direction (16.35); respectively. Furthermore, the indicators of capability development (14.2), core values (15.31), team orientation (15.45), and goals (15.46) received the lowest mean scores in this respect. Among the four dimensions of organizational culture, the highest mean score was related to "mission" in organizational culture and the lowest score was associated with "involvement." Meyer and Allen's organizational commitment model also had three components in which affective commitment in this study obtained the highest score (26.63) and continuance commitment received the lowest score (24.73). In this study, there was a significant correlation between all the components of organizational culture and organizational commitment of employees in administrative units of health care centers $(\mathrm{p}<0.05)$.

Conclusion: Reflecting on all the dimensions and indicators of organizational culture can lead to an escalation of organizational commitment among employees. Furthermore, focus on factors affecting the improvement of continuance commitment can promote organizational commitment of employees in administrative units of health care centers.
\end{abstract}

Keywords: Organizational culture, Organizational commitment, Denison model, Healthcare, Hamedan

\section{Corresponding author:}

Roghayeh Mohammadibakhsh, Deputy Health, Hamadan University of Medical Sciences, Hamadan, Iran.

Tel: +98.9187114177, Fax:+98.8134245411, Email: r.moahhmmadib1@gmail.com

Received: July 17, 2016, Accepted: October 19, 2016, Published: January 2017

iThenticate screening: September 26, 2016, English editing: December 22, 2016, Quality control: January 06, 2017

(C) 2017 The Authors. This is an open access article under the terms of the Creative Commons Attribution-NonCommercialNoDerivs License, which permits use and distribution in any medium, provided the original work is properly cited, the use is non-commercial and no modifications or adaptations are made. 


\section{Introduction}

Today, the importance of human resources as the most effective factor in terms of growth and productivity has been recognized by organizations (1). What is certain is that management of human resources is not merely retaining individuals in organizations; rather, it is linking individuals with organizations as well as creating mutual solidarity between individuals and organizations (2). It should be noted that well-mannered and committed individuals in organizations can be positive and constructive in this respect and take steps in the fulfillment of organizational goals (3). Commitment is referred to as a broad concept for analyzing organizational effectiveness as well as a working attitude, which is directly related to participation and decisions of employees to stay in an organization (4). Affective commitment in this respect is associated with a sense of belonging to an organization as well as personal features and organizational structure, including the amount of pay and manner of supervision. Employees with higher affective commitment are heavily bound to their values and assume themselves more obliged to the completion of organizational goals. Continuance commitment is the perception of the cost of leaving the organization in both financial and nonfinancial terms and the perception of people forced to stay in the organization is taken into consideration. Normative commitment also reflects commitment to continuous employment; that is, a person does not quit an organization because of the pressures imposed by norms, morals, and judgments by other organizations. Each of the dimensions of commitment can have potential impacts associated with absenteeism and decisions to leave an organization (5-9). In this respect, several factors constitute organizational commitment including a sense of psychological well-being and emotional intelligence. However, one of the important factors affecting the establishment of organizational commitment is organizational culture (10-12). Organizational culture, as the most important factor affecting life and identity of an organization, has always been of particular interest to all scholars of management. Organizational culture consists of ideas, values, attitudes, and software that are shared by individuals in organizations; it also refers to perceptions or notions employees have toward an organization (13-19). In humancentered organizations such as health care, organizational culture plays an important role in creating organizational commitment and its success. To strengthen and promote the existing organizational culture in these organizations, various aspects of dominating culture available must be first examined. Employees in administrative units of health care centers in cities as the mainstay of the health system can thus far play a significant role in promoting the goals of the health system by monitoring line and staff personnel. This study aimed to determine the relationship between organizational culture and organizational commitment of employees in administrative health care centers in the cities of Hamedan Province based on the Denison model in 2015.

\section{Material and Methods \\ 2.1. Setting and participants}

In this cross-sectional study, 177 employees of administrative units of health care centers in the cities of Hamedan Province were selected by a multistage stratified sampling method. For this purpose, the health care center located in each city was considered as a class. Then, different units of each class were considered as a cluster by which the study sample was randomly selected according to the list of personnel, and then the questionnaires were distributed for completion by individuals. Considering the type 1 error by $5 \%$, the power equal to $90 \%$, as well as Cochran's test for limited populations; thus, the sample size was determined ( $\mathrm{n}=177$ individuals).

\subsection{Instrument and data collection}

The study instruments used in this study included a demographic questionnaire (including items of age, gender, marital status, employment status, level of education, etc.), the standardized Denison organizational culture survey, and organizational commitment questionnaire by Meyer and Allen (20,21). In this study, organizational culture was evaluated through investigating library documents, searching relevant websites, and completing a Denison organizational culture survey. The questionnaire included 60 items evaluating four dimensions: mission, involvement, adaptability, and consistency. Each of these dimensions also was composed of three indicators (20). The validity of questionnaire also has been confirmed in several research studies, including that by Rahimnia et al. (22). The reliability of the questionnaire in the present study using Cronbach's alpha coefficient was $89 \%$, and it was estimated by $87.6 \%, 70 \%, 73.3 \%$, and $74.1 \%$ for involvement, consistency, adaptability, and mission, respectively. The questionnaire was scored from 5 to 1 based on a Likert-type scale (strongly agree, agree, neutral, disagree, and strongly disagree). The standardized organizational commitment questionnaire by Meyer and Allen had also 24 items for the measurement of affective, normative, and continuance components (21). In a 2007 study by Delgoshaei et al. on the relationship between organizational climate and organizational commitment of employees and managers of training hospitals affiliated by Hamedan University of Medical Sciences using Meyer and Allen's organizational commitment questionnaire, the validity values of $0.789,0.684$, and 0.823 were, respectively, obtained for the dimensions of affective, normative, and continuance organizational commitment using Cronbach's alpha coefficient 
method (23). The reliability of the given questionnaire in this study measured through Cronbach's alpha coefficient method was equal to $82 \%$, and it was $0.82,0.72$, and 0.70 for affective, normative, and continuance dimensions, respectively. Meyer and Allen's questionnaire was based on a Likert-type scale composed of strongly agree, agree, neutral, disagree, and strongly disagree sections and scored from 5 to 1 ; however, items 2, 3, 6, 10, 11, 17, and 20 were scored in a reverse order.

\subsection{Data analysis}

The data obtained were analyzed through the SPSS software version 21 (IBMC Corp., Armonk, NY, USA), descriptive statistics, and the Pearson product-moment coefficient. The level of significance also was considered lower than 0.05 .

\section{Results}

In the present study, $46.6 \%$ of participants were placed in the age range of 40 to 49 years old; $54.8 \%$ of participants were female and $45.2 \%$ were male; $13 \%$ of individuals were also single; $87 \%$ of them were married; $71.2 \%$ participants held bachelor's degrees; and $80.3 \%$ were officially employed in terms of their employment status. The results are shown in Table 1 . In this study, the index of capability development obtained the lowest mean score, and the index of empowerment received the lowest mean score. In total, the mean score of "involvement" in Denison's model of organizational culture was estimated by 46.3. The indices of consistency and core values in this study were assigned with the lowest and the highest mean scores, respectively. Altogether, the mean score of "consistency" in Denison's model of organizational culture was estimated by 46.43 . In the present study, customer orientation and learning indices received the highest and the lowest scores, respectively. In total, the mean score of "adaptability" in Denison's model of organizational culture was estimated by 47.98. Moreover, the index of vision obtained the highest mean score, and the index of goals received the lowest mean score in this research study. In sum, the mean score of "mission" in Denison's organizational culture was estimated by 48.21. In the present study, "mission" received the highest score and "involvement" obtained the lowest mean score. The results are shown in Table 2. Furthermore, the highest scores for organizational commitment in the present study were related to affective, normative, and continuance dimensions, respectively. These results are shown in Table 3. There was a strong, direct, and significant relationship between organizational culture and all its dimensions. Further, there was a direct and significant relationship between organizational commitment and its dimensions. The results are shown in Table 4.

Table 1. Demographic characteristics of participants

\begin{tabular}{|c|c|c|c|}
\hline Value & Index & $\mathrm{n}$ & $\%$ \\
\hline \multirow[t]{4}{*}{ Age (year) } & $20-29$ & 12 & 6.8 \\
\hline & $30-39$ & 73 & 41.2 \\
\hline & $40-49$ & 83 & 46.9 \\
\hline & $50-59$ & 9 & 5.1 \\
\hline \multirow[t]{2}{*}{ Gender } & Male & 80 & 45.2 \\
\hline & Female & 97 & 54.8 \\
\hline \multirow[t]{2}{*}{ Marital status } & Single & 23 & 13 \\
\hline & Married & 154 & 87 \\
\hline \multirow[t]{5}{*}{ Educational status } & Diploma & 4 & 2.3 \\
\hline & Associate degree & 18 & 10.2 \\
\hline & Bachelor & 126 & 71.2 \\
\hline & MA & 26 & 14.7 \\
\hline & Doctor & 3 & 1.6 \\
\hline \multirow[t]{6}{*}{ Work experience (year) } & $<5$ & 15 & 8.5 \\
\hline & $5-10$ & 37 & 20.9 \\
\hline & $10-15$ & 34 & 19.2 \\
\hline & $15-20$ & 44 & 24.9 \\
\hline & $20-25$ & 31 & 17.5 \\
\hline & $>25$ & 16 & 9 \\
\hline \multirow[t]{4}{*}{ Employment status } & Contractual & 15 & 8.5 \\
\hline & Treaty & 10 & 5.6 \\
\hline & Experimental official & 10 & 5.6 \\
\hline & Official & 142 & 80.3 \\
\hline
\end{tabular}


Table 2. Denison organizational culture of health centers in Hamedan province in 2015 townships

\begin{tabular}{|l|l|l|l|}
\hline Value & $\mathrm{n}$ & Mean & SD \\
\hline Involvement & 177 & 46.3 & 9.18 \\
\hline consistency & 177 & 46.43 & 10.01 \\
\hline Adaptability & 177 & 47.98 & 8.85 \\
\hline Mission & 177 & 48.21 & 10.28 \\
\hline Total organizational culture points & 177 & 188.49 & 30.61 \\
\hline
\end{tabular}

Table 3. Mean and standard deviation of organizational commitment and its dimensions

\begin{tabular}{|l|l|l|}
\hline Value & Mean & SD \\
\hline Affective commitment & 26.63 & 5.25 \\
\hline Continuance commitment & 24.73 & 3.25 \\
\hline Normative commitment & 25.31 & 4.17 \\
\hline Total score of organizational commitment & 76.67 & 10.64 \\
\hline
\end{tabular}

Table 4. Spearman correlation coefficient between dimensions and between organizational culture and organizational commitment and its dimensions

\begin{tabular}{|l|l|l|l|l|l|l|l|l|l|}
\hline Variables & $\begin{array}{l}\text { Organizational } \\
\text { Culture }\end{array}$ & Involvement & Consistency & Adaptability & Mission & $\begin{array}{l}\text { Organizational } \\
\text { Commitment }\end{array}$ & $\begin{array}{l}\text { Affective } \\
\text { commitment }\end{array}$ & $\begin{array}{l}\text { Continuance } \\
\text { commitment }\end{array}$ & $\begin{array}{l}\text { Normative } \\
\text { commitment }\end{array}$ \\
\hline $\begin{array}{l}\text { Organizational } \\
\text { Culture }\end{array}$ & 1 & & & & & & & & \\
\hline Involvement & 0.822 & 1 & & & & & & & \\
\hline Consistency & 0.821 & 0.672 & 1 & & & & & & \\
\hline Adaptability & 0.797 & 0.517 & 0.540 & 1 & & & & & \\
\hline Mission & 0.758 & 0.455 & 0.407 & 0.527 & 1 & & & & \\
\hline $\begin{array}{l}\text { Organizational } \\
\text { Commitment }\end{array}$ & 0.423 & 0.379 & 0.319 & 0.341 & 0.316 & 1 & & & \\
\hline $\begin{array}{l}\text { Affective } \\
\text { Commitment }\end{array}$ & 0.479 & 0.425 & 0.297 & 0.424 & 0.392 & 0.916 & 1 & & \\
\hline $\begin{array}{l}\text { Continuance } \\
\text { Commitment }\end{array}$ & 0.198 & 0.173 & 0.216 & 0.151 & 0.96 & 0.665 & 0.421 & 1 & \\
\hline $\begin{array}{l}\text { Normative } \\
\text { Commitment }\end{array}$ & 0.322 & 0.298 & 0.273 & 0.218 & 0.237 & 0.881 & 0.750 & 0.388 & 1 \\
\hline
\end{tabular}

\section{Discussion and conclusions}

Among the 12 indicators of organizational culture in this study, the lowest mean scores were, respectively, related to capability development (14.2), core values (15.31), team orientation (15.45), and goals (15.46), which showed that health care centers in the given cities did benefited from these indicators at a desirable level and required greater attention and sensitivity in terms of their improvement. In this study, the highest and the lowest mean scores were assigned to the dimensions of mission and involvement in organizational culture. In an investigation by Gillespie et al. (24), the highest score was related to adaptability, which was not in line with the results of the present study. In this study, involvement did not receive a desirable score by the employees of the administrative units of health care centers located in the cities of Hamedan Province, which required greater sensitivity in this respect. Considering the findings related to organizational commitment, the highest mean score obtained was associated with affective commitment (26.63), and the lowest mean score was related to the continuance commitment (24.73). In the study by Delgoshaei et al., the highest score was for the affective commitment, which was consistent with the findings of the present study. But the normative commitment received the lowest mean score, which was different from the results of the present study (23). There also was a significant relationship between "mission" in organizational culture and organizational commitment. It should be noted that the reliance of mission culture is on strategic orientation of organization, foresight, and achievement to ideal objectives. Therefore, the presence of mission and vision in an organization makes the employees authenticate their identities with their organizations.

With recapitulating this type of culture for organizational employees, it is expected that they have a profound understanding of organizational mission, which is an additional step in which to explain the current job roles and duties of individuals (25-28). As well, there was a significant relationship between the "adaptability" in organizational culture and organizational commitment. It should be noted that the culture of adaptability is an 
incentive for behavioral norms that can support organizations in discovering and interpreting environmental symbols. Such organizations must have accelerated responses to environmental demands. In fact, adaptability of employees to environmental changes makes employees increase their commitment to organizations and consider organizations as part of their own identity. Organizations with high adaptability power are often endowed with more efficiency and effectiveness. Adaptability also enables organizations to respond better to an organization's internal and external environment (25-28). Additionally, there was a significant relationship between "involvement" in organizational culture and organizational commitment. In fact, the first emphasis by the dimension of involvement is on engaging in tasks according to changing and accelerating expectations in an organization's external environment. The purpose of an organization in this case is to respond quickly to the needs and enhance efficiency. From the perspective of this culture, involvement and participation in the activities of an organization increase the sense of accountability and commitment of individuals. In this respect, values derived from high levels of involvement have certain organizational positions in team orientation and create a sense of ownership and accountability at work. Such a sense of ownership enhances commitment to the organization and improves the capabilities of employees in uncertain conditions (25-28). There was also a direct and significant relationship between "consistency" in organizational culture and organizational commitment.

In the culture of consistency, communications are a guaranteed process in which to exchange information. In this case, a common vision and value are created among members of an organization, which leads to a growth in coordination and understanding of personnel from each other and their organization. Thus, internal affairs are highlighted in organizations wherein the culture of stability and consistency is dominant. Such an organization has a culture that highlights continuity in behavior, consistency of individuals with common traditions, cooperation, and collaboration that can augment their commitment to the organization (25-28). Finally, a significant relation among organizational culture and its dimensions and organizational commitment and its dimensions was found in the present study. The results of a research study by Ziaee entitled "Examining the relationship between organizational culture and organizational commitment of employees in the libraries of Tehran University based on the Denison model" indicated a significant relationship between organizational culture and its dimensions (involvement, consistency, adaptability, and mission) and organizational commitment, which was in agreement with the findings of the present study (28). Furthermore, the findings showed that organizational culture was in a significant relationship with organizational commitment, i.e., the culture of an organization reveals the attitudes of individuals toward the organization and this attitude will affect the type of behavior in the workplace. Consequently, if members of organizations have common goals, values, and beliefs, they eventually find emotional attachment to the organization and remain committed and loyal to it. Taking all the dimensions and indicators of organizational culture into account can lead to an increase in employee commitment to the organization. Creating positive interactions, providing easy access to managers, observing equity and fairness in dealing with employees, establishing a constructive working environment, and determining financial and nonfinancial rewards to boost employees' spirit will help them to understand that they are important to managers. Attention to team orientation and group work, creation and enhancement of a sense of organizational identity, and finally organizational commitment in the health care centers within cities can augment commitment among employees (29).

\section{Acknowledgments:}

This study was funded and supported by the Hamadan University of Medical. We appreciate everyone who assisted us in conducting this study.

\section{Conflict of Interest:}

There is no conflict of interest to be declared.

Authors' contributions:

All authors contributed to this project and article equally. All authors read and approved the final manuscript.

\section{References:}

1) Kabene SM, Orchard C, Howard JM, Soriano MA, Leduc R. The importance of human resources management in health care: a global context. Hum Resour Health. 2006;4:20. doi: 10.1186/1478-4491-420, PMid: 16872531, PMCid: PMC1552082

2) Cometto G, Campbell J. Investing in human resources for health: beyond health outcomes. Hum Resour Health. 2016;14:51. doi: 10.1186/s12960-016-0147-2, PMid: 2752694, PMCid: PMC4986336 
3) Ren Z, Song P, Theodoratou E, Guo S, An L. China's human resources for maternal and child health: a national sampling survey. BMC Health Serv Res. 2015;15:561. doi: 10.1186/s12913-015-1238-9, PMid: 26674783, PMCid: PMC4682222

4) Okechukwu Agwu M. Organizational Culture and Employees Commitment in Bayelsa State Civil Service. J Manag Policies and Practices. 2013;1(1):35-45.

5) Vermeeren B, Steijn B, Tummers L, Lankhaar M, Poerstamper R-J, Van Beek S. HRM and its effect on employee, organizational and financial outcomes in health care organizations. Hum Resour Health. 2014;12:35. doi: 10.1186/1478-4491-12-35, PMid: 24938460, PMCid: PMC4075604

6) Daneshkohan A, Zarei E, Mansouri T, Maajani K, Ghasemi MS, Rezaeian M. Factors Affecting Job Motivation among Health Workers: A Study From Iran. Glob J Health Sci. 2015;7(3):153-60.

7) Najafi L, Hamidi Y, Ghiasi M, Emami H. Performance evaluation and its effects on employees' job motivation in Hamedan City health centers. Aust J Basic \& Appl Sci. 2011;5(12):1761-5.

8) Dwivedi S, Kaushik S, Luxmi. Impact of Organizational Culture on Commitment of Employees: An Empirical Study of BPO Sector in India. Vikalpa. 2014;39(3):77-92. doi: 10.1177/0256090920140306

9) Amponsah-Tawiah K, Mensah J. Occupational Health and Safety and Organizational Commitment: Evidence from the Ghanaian Mining Industry. Saf Health Work. 2016;7(3):225-30. doi: 10.1016/j.shaw.2016.01.002, PMid: 27630792, PMCid: PMC5011093

10) Barbazza E, Langins M, Kluge H, Tello JE. Health workforce governance: processes, tools and actors towards a competent health workforce for integrated health services delivery. Health Policy. 2015;119(2):1645-53. doi: 10.1016/j.healthpol.2015.09.009, PMid: 26489924

11) Dieleman M, Shaw DMP, Zwanikken P. Improving the implementation of health workforce policies through governance: a review of case studies. Hum Resour Health. 2011;9:10. doi: 10.1186/1478-4491-910, PMid: 21486438, PMCid: PMC3094272

12) Buchan J, Duffield C, Jordan A. 'Solving' nursing shortages: do we need a new agenda? . J Nurs Manag. 2015;23(5):543-5. doi: 10.1111/jonm.12315, PMid: 26138078

13) Dussault G, Badr E, Haroen H, Mapunda M, Soebagja A, Mars AST, et al. Follow-up on commitments at the Third Global Forum on Human Resources for Health: Indonesia, Sudan, Tanzania. Hum Resour Health. 2016;14:16. doi: 10.1186/s12960-016-0112-0, PMid: 27117822, PMCid: PMC4847370

14) Zurn P, Dal Poz MR, Stilwell B, Adams O. Imbalance in the health workforce. . Human Resources for Health. 2004;2:13-0. doi: 10.1186/1478-4491-2-13, PMid: 15377382, PMCid: PMC526216

15) Reich MR. The politics of health sector reform in developing countries: three cases of pharmaceutical policy. Health Policy. 1995;32(1-3):47-77. doi: 10.1016/0168-8510(95)00728-B

16) Zinnen V, Paul E, Mwisongo A, Nyato D, Robert A. Motivation of human resources for health: a case study at rural district level in Tanzania. Int $J$ Health Plann Manage. 2012;27:327-47. doi: 10.1002/hpm.2117, PMid: 22714251

17) Walt G, Gilson L. Reforming the health sector in developing countries: the central role of policy analysis. Health Policy Plan. 1994;9:353-70. doi: 10.1093/heapol/9.4.353, PMid: 10139469

18) Vujicic M, Zurn P, Diallo K, Adams O, Dal Poz MR. The role of wages in the migration of health care professionals from developing countries. Hum Resour Health. 2004;2(1):3. doi: 10.1186/1478-4491-2-3, PMid: 15115549, PMCid: PMC419378

19) Malat J. Social distance and patient's ratings of health care providers. J Health Soc Behav. 2001;42:360-72. doi: 10.2307/3090184, PMid: 11831137

20) Denison DR. Corporate Culture and Organizational Effectiveness. New York: John Wiley \& Sons; 1990.

21) Meyer JP, Stanley DJ, Herscovitch L, Topolnytsky L. Affective, Continuance, and Normative Commitment to the Organization: A Meta-analysis of Antecedents, Correlates, and Consequences. J Vocational Behavior. 2002;61(1):20-52. doi: 10.1006/jvbe.2001.1842

22) Rahimnia F, Alizadeh M. Aspects of organizational culture From the perspective of Faculty of the Ferdosi University in Mashhad based on Denison Model. J Educational Studies and Psychology of the Ferdowsi Uni. 2008;10(1):147-70.

23) Delgoshaei B, Tofighi S, Kermani B. The relationship between organizational climate and organizational commitment in teaching hospitals of Hamedan University of medical sciences. Horizon Med Sci. 2009; 14(4):60-8.

24) Gillespie AM, Denison D, Haaland S, Smerek R, Neale W. Linking organizational culture and customer satisfaction: Result from two companies in different industries. European Journal of work and organizational psychology. 2008;3(1):13-24. doi: 10.1080/13594320701560820 
25) Efendi F. Health worker recruitment and deployment in remote areas of Indonesia. Rural Remote Health. 2012;12:1-6.

26) Kuhlmann E, Batenburg R, Dussault G. Health workforce governance in Europe: where are we going? . Health Policy. 2015;119(12):1515-6. doi: 10.1016/j.healthpol.2015.10.008, PMid: 26563633

27) Hastings SE, Armitage GD, Mallinson S, Jackson K, Suter E. Exploring the relationship between governance mechanisms in healthcare and health workforce outcomes: a systematic review. BMC Health Serv Res. 2014;14:479. doi: 10.1186/1472-6963-14-479, PMid: 25280467, PMCid: PMC4282499

28) Ziaei MS, Roshandel T, Nargesian A. Investigation of Relation between Organizational Culture and Organizational Commitment in Libraries Personnel of University of Tehran: Based on Dennison's Organizational Culture Model. J Academic Librarianship and Information Research. 2011;45(55):49-77.

29) Hamidi Y, Barati M. Communication skills of heads of departments: Verbal, listening, and feedback skills. J Research in Health Sciences. 2011;11(2):91-6. PMid: 22911958 